\title{
STUDIES ON GENETIC POLYMORPHISM IN Luffa aegyptica LANDRACES USING RAPD -PCR
}

\author{
Salma A.E. Soaud", S.M. Abd-EI Sayyed, E.I. Mahgoub and H.A. Wafa \\ Genet. Dept., Fac. Agric., Zagazig Univ., Egypt
}

Received: 06/12/2016 ; Accepted: 01/02/2017

\begin{abstract}
Genetic polymorphism of eight open and self pollinated Luffa landraces, which collected from four Egyptian regions, Ismailia, El-Arish, Zagazig and Meet-Gamr, was studied. Four selected decamer primers, out of eight screened, generated a total of 46 RAPD fragments of which 31 were polymorphic (67\%). The number of amplification products of each primer varied from 8 (OPA04) to 16 (OPC-02) with average 11.5 per primer. The band size of PCR products ranged from $100 \mathrm{bp}$ (OPC-02) to 1530 bp (OPC-06). The average similarity coefficient between Luffa landraces based on combined RAPD-PCR products of the four used primers was 0.783 , indicating a clear relationship between such entries and showing that genomes were not much different from each other. The highest similarity coefficient $(0.889)$ was found between the selfed Ismailia landrace and selfed Meet-Gamr or selfed El-Arish landrace. But, the lowest similarity coefficient $(0.667)$ was detected between openpollinated landrace of Zagazig and each of selfed Meet-Gamr and open-pollinated El-Arish landrace. The largest distance was detected between open pollinated landrace of Zagazig and each of selfed landrace of Meet-Gamr as well as the open pollinated landrace of El-Arish. While the smallest genetic distance was observed between selfed landrace of Ismailia and each of selfed landrace of Meet-Gamr and El-Arish landrace. The constructed dendrogram distributed the eight Luffa landraces into three major clusters, the largest one included five members and divided into two sub-clusters. RAPD-PCR technique appeared to be suitable in revealing genetic variability, relatedness and consequently genetic polymorphism among the studied luffa landraces.
\end{abstract}

Key words: Luffa, molecular markers, polymorphism, RAPD-PCR, similarity coefficient.

\section{INTRODUCTION}

Loof, Luffa aegyptica L., is the common name of sponge gourd. The plant is diploid $(2 \mathrm{n}$ $=26$ ), annual, climbing vine and cross pollinated crop. Luffa is grown for it's fruits which are used as bath sponge (Terh, 2007). Also, it has a medicinal importance (Partap et al., 2012; Modi and Kumar, 2014). This plant can tolerate a wide range of environmental conditions and distributing in many regions in the world as well as in Egypt forming various landraces that having different genetic characterises. Polymerase chain reaction (PCR) technology had led to the development of several novel genetic assays based on selective DNA amplification. RAPD assay detects nucleotide sequences of polymorphic DNA using only a

\footnotetext{
* Corresponding author: Tel. : +201120963898

E-mail address: salmasoaud92@yahoo.com
}

single primer of arbitrary nucleotide sequence. This technique always allows the examination of genomic variations without prior knowledge of DNA sequences, and is especially useful for revealing variations in a species with low genetic variability

The goal of our investigation is to study the genetic polymorphism at the molecular level among some Luffa landraces, open and selfed pollinated, collected from four regions of Egypt using random amplified polymorphic DNA, RAPD technique.

\section{MATERIALS AND METHODS}

The used materials in this study were Luffa landraces collected from four regions of Egypt, 
Ismailia, El-Arish, Zagazig and Meet-Gamr. Natural seeds of these landraces were obtained from private and commercial sources. The obtained seeds were sown in summer season of 2014 at the farm of Fac. Agric., Zagazig Univ. and at a private farm in Abo-kabeer District, Sharkia Governorate, Egypt. At flowering, the plants were bagged and self- pollinated .In the same time, some plants were open- pollinated. At fruit maturity, the self and open pollinated seeds were obtained. For studying RAPD procedure, some seeds of all Luffa landraces were germinated. Genomic DNA was extracted from young leaves of each entry according to Dellaporta et al. (1983). The polymerase chain reaction (PCR) was used for examining RAPD using some decamer random primers, obtained from Metabion GMBH Germany, having the following sequence and operon codes as shown in Table 1.

The amplification protocol was carried out according to the method of Williams et al. (1990) and adopted by Hoque and Rabbani (2009) and Rasmi and Steelathakumary (2011).

The amplified products plus loading dye, ethidium bromide, were subjected to horizontal gel electrophoresis using 1.4\% agarose gel. The stained gels were visualized by UV light and photographed. For data analysis, all RAPD bands were counted The visible bands were scored as (1) for present and (0) for absent, separately for each individual and primer. DNA bands size was determined and compared with DNA ladder using TL120ID marker as molecular size marker. The scores were combined for forming a single data matrix to estimate genetic distances between all entries and to construct linkage dendrogram according to Nie's approach as reported by Sharma (2006). The similarity index vales between the RAPD profiles of any two individuals on the same gel were calculated from RAPD markers according to Lynch (1991).

\section{RESULTS AND DISCUSSION}

Screening of the eight random primers revealed that only four decamer primers; OPA04, OPA-07, OPC-02 and OPC-06; produced clear bands. RAPD banding profiles of the studied Luffa landraces generated by the four used primers are shown in Fig. 1, while survey of amplified RAPD bands after using these four primers is given in Table 2. A total of 46 RAPD fragments were detected. The number of amplification products of each primer varied from 8 (OPA-04) to 16 (OPC-02) with average of 11.5 per primer. The band size of PCR Products ranged from 100 (OPC-02) to $1530 \mathrm{bp}$ (OPC-06). For instance, primer OPA-04 produced eight bands and one band of them was polymorphic (12\% polymorphism). Results in Table 3 assure such polymorphic nature. The fragment sizes generated by this primer ranged from 225 to $1320 \mathrm{bp}$. All bands were observed in all Luffa landraces expect the band size 355 which was absent in open-pollinated landraces of Meet-Gamr and El-Arish. Also, primer (OPA-07) produced nine bands and six bands of them were polymorphic (66\%polymorphism) as shown in Table 3. But the band 7, of 465 bp in size, was only detected in the open -pollinated landrace of Zagazig as a marker characterizing this landrace. However, primer (OPC-02) produced sixteen bands and thirteen bands were polymorphic ( $81 \%$ polymorphism) as shown in Table 3. There were unique bands; band 2 of $900 \mathrm{bp}$ in size characterized open pollinated Zagazig landrace, band 4 of $720 \mathrm{bp}$ in size was in selfed El-Arish landrace, 9 of $280 \mathrm{bp}$ in size was in open pollinated El-Arish landrace, bands 12 and 16 characterizing the selfed Meet-Gamr landrace and band 13 of $150 \mathrm{bp}$ in size was also in selfed El-Arish landrace. While, primer (OPC-06) gave thirteen bands and eleven bands were polymorphic ( $84 \%$ polymorphism).

Table 1. Sequence and operon codes of the random primers used for detection of variation in Luffa

\begin{tabular}{lllc}
\hline No. & Primer code & Sequence 5-to3- & GC (\%) \\
\hline $\mathbf{1}$ & OPA-04 & AATCGGGCTG & $60 \%$ \\
$\mathbf{2}$ & OPA-07 & GAAACGGGTG & $60 \%$ \\
$\mathbf{3}$ & OPC-02 & GTGAGGCGTC & $70 \%$ \\
$\mathbf{4}$ & OPC-06 & GAACGGACTC & $60 \%$ \\
\hline
\end{tabular}




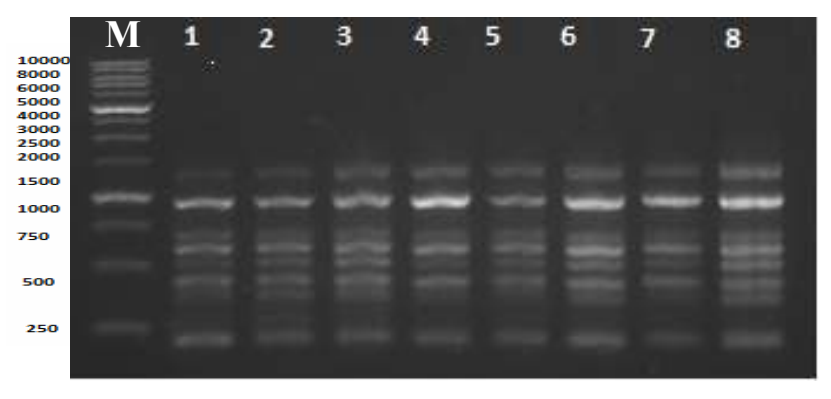

Primer OPA-04

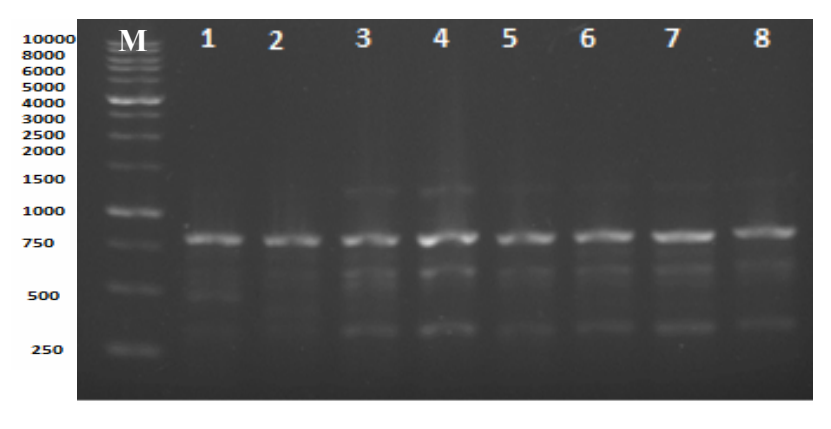

Primer OPA-07

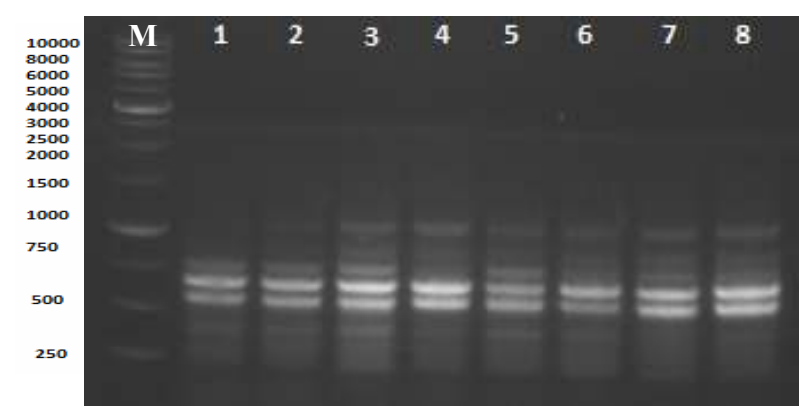

Primer OPC-02

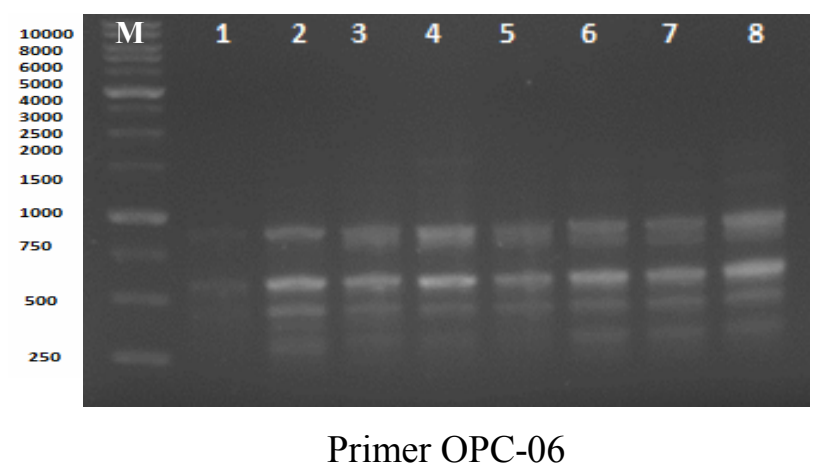

Fig. 1. RAPD banding profiles of the studied $L$ uffa landraces after used primers 1=Zag (o) 2= Zag(s) 3=Is(O) 4=Is(s) 5=Mit (o) 6=Mit(s) 7=El-Arish (o) 8=El-Arish (s) M= marker 
Table 2. Survey of amplified RAPD bands in the studied $L u f f a$ landraces after used primers

\begin{tabular}{|c|c|c|c|c|c|c|c|c|c|c|}
\hline \multirow{2}{*}{ 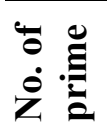 } & \multirow[t]{2}{*}{ Band\#. } & \multirow[t]{2}{*}{ M.S } & \multirow{2}{*}{$\begin{array}{c}\text { zag } \\
\text { (o) }\end{array}$} & \multirow{2}{*}{$\begin{array}{c}\text { zag } \\
\text { (s) }\end{array}$} & \multirow{2}{*}{$\begin{array}{l}\text { IS } \\
\text { (o) }\end{array}$} & \multirow{2}{*}{$\begin{array}{l}\text { IS } \\
\text { (s) }\end{array}$} & \multirow{2}{*}{$\begin{array}{l}\text { Mit } \\
\text { (o) }\end{array}$} & \multirow{2}{*}{$\begin{array}{c}\text { Mit } \\
\text { (s) }\end{array}$} & \multicolumn{2}{|c|}{ El-Arish El-Arish } \\
\hline & & & & & & & & & (o) & (s) \\
\hline \multirow{7}{*}{ 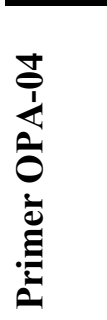 } & 1 & 1320 & 1 & 1 & 1 & 1 & 1 & 1 & 1 & 1 \\
\hline & 2 & 970 & 1 & 1 & 1 & 1 & 1 & 1 & 1 & 1 \\
\hline & 3 & 960 & 1 & 1 & 1 & 1 & 1 & 1 & 1 & 1 \\
\hline & 4 & 590 & 1 & 1 & 1 & 1 & 1 & 1 & 1 & 1 \\
\hline & 5 & 505 & 1 & 1 & 1 & 1 & 1 & 1 & 1 & 1 \\
\hline & 6 & 415 & 1 & 1 & 1 & 1 & 1 & 1 & 1 & 1 \\
\hline & 7 & 355 & 1 & 1 & 1 & 1 & 0 & 1 & 0 & 1 \\
\hline \multirow{10}{*}{ 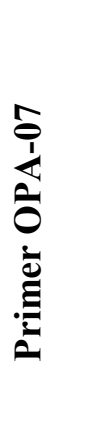 } & 8 & 225 & 1 & 1 & 1 & 1 & 1 & 1 & 1 & 1 \\
\hline & 1 & 1220 & 1 & 0 & 1 & 1 & 1 & 1 & 1 & 1 \\
\hline & 2 & 790 & 1 & 1 & 1 & 1 & 1 & 1 & 1 & 1 \\
\hline & 3 & 680 & 0 & 1 & 1 & 0 & 0 & 1 & 1 & 0 \\
\hline & 4 & 623 & 0 & 0 & 0 & 0 & 1 & 0 & 0 & 1 \\
\hline & 5 & 580 & 1 & 1 & 1 & 1 & 1 & 1 & 1 & 1 \\
\hline & 6 & 515 & 1 & 0 & 1 & 0 & 0 & 0 & 1 & 0 \\
\hline & 7 & 465 & 1 & 0 & 0 & 0 & 0 & 0 & 0 & 0 \\
\hline & 8 & 405 & 0 & 1 & 1 & 0 & 0 & 0 & 1 & 0 \\
\hline & 9 & 315 & 1 & 1 & 1 & 1 & 1 & 1 & 1 & 1 \\
\hline \multirow{15}{*}{ 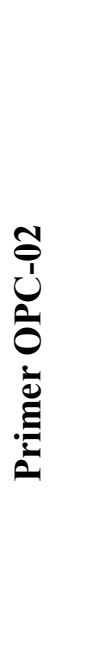 } & 1 & 990 & 1 & 1 & 1 & 1 & 1 & 1 & 1 & 1 \\
\hline & 2 & 900 & 1 & 0 & 0 & 0 & 0 & 0 & 0 & 0 \\
\hline & 3 & 790 & 0 & 0 & 1 & 1 & 0 & 1 & 1 & 1 \\
\hline & 4 & 720 & 0 & 0 & 0 & 0 & 0 & 0 & 0 & 1 \\
\hline & 5 & 680 & 1 & 1 & 1 & 1 & 1 & 0 & 1 & 0 \\
\hline & 6 & 580 & 1 & 1 & 1 & 1 & 1 & 1 & 1 & 1 \\
\hline & 7 & 490 & 1 & 1 & 1 & 1 & 1 & 1 & 1 & 1 \\
\hline & 8 & 350 & 1 & 1 & 1 & 1 & 1 & 1 & 0 & 1 \\
\hline & 9 & 280 & 0 & 0 & 0 & 0 & 0 & 0 & 1 & 0 \\
\hline & 10 & 250 & 1 & 1 & 1 & 0 & 0 & 0 & 0 & 1 \\
\hline & 11 & 225 & 0 & 0 & 0 & 0 & 1 & 1 & 0 & 0 \\
\hline & 12 & 190 & 0 & 0 & 0 & 0 & 0 & 1 & 0 & 0 \\
\hline & 13 & 150 & 0 & 0 & 0 & 0 & 0 & 0 & 1 & 0 \\
\hline & 14 & 130 & 0 & 0 & 1 & 0 & 0 & 0 & 0 & 1 \\
\hline & 15 & 115 & 1 & 1 & 0 & 1 & 1 & 0 & 0 & 0 \\
\hline \multirow{14}{*}{ 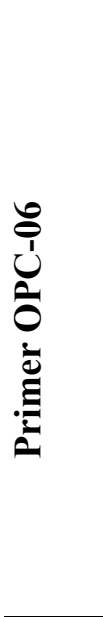 } & 16 & 100 & 0 & 0 & 0 & 0 & 0 & 1 & 0 & 0 \\
\hline & 1 & 1530 & 0 & 0 & 1 & 1 & 0 & 1 & 1 & 1 \\
\hline & 2 & 1300 & 1 & 0 & 0 & 0 & 0 & 0 & 0 & 0 \\
\hline & 3 & 1200 & 0 & 1 & 1 & 1 & 0 & 1 & 1 & 1 \\
\hline & 4 & 1070 & 0 & 1 & 1 & 0 & 0 & 0 & 0 & 0 \\
\hline & 5 & 865 & 1 & 1 & 1 & 1 & 1 & 1 & 1 & 1 \\
\hline & 6 & 790 & 0 & 0 & 1 & 1 & 1 & 1 & 1 & 1 \\
\hline & 7 & 660 & 1 & 0 & 0 & 0 & 1 & 0 & 0 & 0 \\
\hline & 8 & 570 & 1 & 1 & 1 & 1 & 1 & 1 & 1 & 1 \\
\hline & 9 & 430 & 0 & 1 & 1 & 1 & 1 & 1 & 1 & 1 \\
\hline & 10 & 350 & 1 & 1 & 0 & 0 & 0 & 0 & 0 & 0 \\
\hline & 11 & 300 & 1 & 0 & 1 & 1 & 0 & 1 & 1 & 1 \\
\hline & 12 & 270 & 0 & 1 & 0 & 0 & 1 & 0 & 0 & 0 \\
\hline & 13 & 240 & 1 & 0 & 0 & 0 & 0 & 0 & 0 & 0 \\
\hline
\end{tabular}


Table 3. Polymorphism detected by RAPD Primers among studied Luffa landraces

\begin{tabular}{lcccc}
\hline $\begin{array}{c}\text { Primer } \\
\text { code }\end{array}$ & $\begin{array}{c}\text { No. of scorable } \\
\text { bands }\end{array}$ & $\begin{array}{c}\text { No. of Polymophic } \\
\text { bands }\end{array}$ & $\begin{array}{c}\text { No. of monomorphic } \\
\text { bands }\end{array}$ & $\begin{array}{c}\text { Percent of } \\
\text { polymorphism }\end{array}$ \\
\hline OPA-04 & 8 & 1 & 7 & $12 \%$ \\
OPA-07 & 9 & 6 & 3 & $66 \%$ \\
OPC-02 & 16 & 13 & 3 & $81 \%$ \\
OPC-06 & 13 & 11 & 2 & $84 \%$ \\
Total & 46 & 31 & 15 & \\
\hline
\end{tabular}

Two bands, band 2 of $1300 \mathrm{bp}$ and band 13 of $240 \mathrm{bp}$, characterizing the open pollinating landrace of Zagazig and serving as molecular markers for this landrace (Table 3). It is clear that primer OPC-06 showed the highest polymorphism, whereas primer OPA-04 showed the lowest polymorphism. In this connection, Hoque and Rabbani (2009) assessed genetic relationship among twenty eight accessions of Bangradish ridge gourd Luffa using RAPD markers. Four primers generated a total of 27 RAPD fragment of which 22 were polymorphic $(81.5 \%)$, and the bands ranged from 50 to 1500 bp in size. Our conclusions agreed with those reported of such authors. Mohammed et al. (2012) used RAPD marker to evaluate a collection of smooth and ridge gourd and stated the effectiveness of such markers in assessing molecular polymorphism. A similarity coefficients matrix, that used to establish the level of relatedness, among all Luffa landraces based on combined data of RAPD -PCR products for the four primers was computed and given in Table 4. The highest similarity coefficient $(0.889)$ was found between the selfed Ismailia landrace and selfed Meet-Gamr or selfed El-Arish landraces. But, the lowest similarity coefficient (0.667) was detected between open-pollinated landrace of Zagazig and each of selfed Meet-Gamr and open-pollinated El-Arish landraces. The average similarity coefficient over all the studied Luffa landraces based on combined RAPD-PCR products of the four primers was 0.783 . This average value might indicate the existence of clear relationship between these studied Luffa landraces and their genomes were not very much different from each other. The present/absent matrix of genetic distances between Luffa landraces was calculated from combined data of RAPD-PCR products for the four primer and illustrated in Table 5. These distances ranged from 2.45 to 4.36 . The largest distances was detected between open pollinated landrace of Zagazig and each of selfed landrace of MeetGamr as well as the open pollinated landrace of El-Arish. While the smallest genetic distances was observed between selfed landrace of Ismailia and each of selfed landrace of MeetGamr and El-Arish. However, the genetic distances between most of the other landraces were approximately equal or having similar scores. In this connection, Xia and Xiang (2008) pointed out the existence of abundant genetic divergence among twenty six accessions of ridge gourd Luffa on the basis of RAPD markers, the average diversity index was 0.325. However, Bharathi et al. (2011) found wide range of molecular divergence among a collection of Indian gourd using twenty one RAPD primers. Also, Mohammed et al. (2012) studied genetic similarity and divergence among a collection of smooth and ridge gourds using DNA-RAPD primer and confirmed the effectiveness of DNA markers in assessing molecular polymorphism. The dendrogram produced from genetic distances between the studied Luffa landraces based on RAPD-PCR product over all used primers is given in Fig. 2. Dendrogram results revealed the eight tested Luffa landraces were distributed into three clusters. Cluster I, the largest one, included five landraces and divided into two sub-clusters. The first sub-cluster aggregated the three selfed landraces from El-Arish, Meet-Gamr and Ismailia together. But, the second sub-cluster contained the two open pollinated landraces of 
Table 4. Similarity coefficients (Dice measure) among the studied Luffa landraces based on combined analysis of amplified RAPD-PCR products after using all primers

\begin{tabular}{lcccccccc}
\hline Landrace & $\begin{array}{c}\text { Zag } \\
(\mathbf{O})\end{array}$ & $\begin{array}{c}\text { Zag } \\
(\mathbf{S})\end{array}$ & $\begin{array}{c}\text { IS } \\
(\mathbf{O})\end{array}$ & $\begin{array}{c}\text { IS } \\
(\mathbf{S})\end{array}$ & $\begin{array}{c}\text { Mit } \\
(\mathbf{O})\end{array}$ & $\begin{array}{c}\text { Mit } \\
(\mathbf{S})\end{array}$ & $\begin{array}{c}\text { El-Arish } \\
(\mathbf{O})\end{array}$ & $\begin{array}{c}\text { El-Arish } \\
(\mathbf{S})\end{array}$ \\
\hline Zag (O) & 1.000 & & & & & & & \\
Zag (S) & 0.750 & 1.000 & & & & & & \\
IS (O) & 0.733 & 0.828 & 1.000 & & & & & \\
IS(S) & 0.764 & 0.792 & 0.877 & 1.000 & & & & \\
Mit (O) & 0.741 & 0.769 & 0.714 & 0.824 & 1.000 & & & \\
Mit (S) & 0.667 & 0.727 & 0.847 & 0.889 & 0.755 & 1.000 & & \\
El-Arish (O) & 0.667 & 0.727 & 0.881 & 0.852 & 0.717 & 0.821 & 1.000 & \\
El-Arish (S) & 0.702 & 0.727 & 0.881 & 0.889 & 0.755 & 0.857 & 0.786 & 1.000 \\
\hline
\end{tabular}

Table 5. Genetic distances, calculated as the total number of RAPD bands differences, among the studied Luffa landraces based on combined analysis of amplified RAPD-PCR products after using all primers

\begin{tabular}{lcccccccc}
\hline Landrace & $\begin{array}{c}\text { Zag } \\
(\mathbf{O})\end{array}$ & $\begin{array}{c}\text { Zag } \\
(\mathbf{S})\end{array}$ & $\begin{array}{c}\text { IS } \\
(\mathbf{O})\end{array}$ & $\begin{array}{c}\text { IS } \\
(\mathbf{S})\end{array}$ & $\begin{array}{c}\text { Mit } \\
(\mathbf{O})\end{array}$ & $\begin{array}{c}\text { Mit } \\
(\mathbf{S})\end{array}$ & $\begin{array}{c}\text { El-Arish } \\
(\mathbf{O})\end{array}$ & $\begin{array}{c}\text { El-Arish } \\
(\mathbf{S})\end{array}$ \\
\hline Zag (O) & 0.00 & & & & & & & \\
Zag (S) & 3.74 & 0.00 & & & & & & \\
IS (O) & 4.00 & 3.16 & 0.00 & & & & & \\
IS (S) & 3.61 & 3.32 & 2.65 & 0.00 & & & & \\
Mit (O) & 3.74 & 3.46 & 4.00 & 3.00 & 0.00 & & & \\
Mit (S) & 4.36 & 3.87 & 3.00 & 2.45 & 3.61 & 0.00 & & \\
El-Arish (O) & 4.36 & 3.87 & 2.65 & 2.83 & 3.87 & 3.16 & 0.00 & \\
El-Arish (S) & 4.12 & 3.87 & 2.65 & 2.45 & 3.61 & 2.83 & 3.46 & 0.00 \\
\hline
\end{tabular}




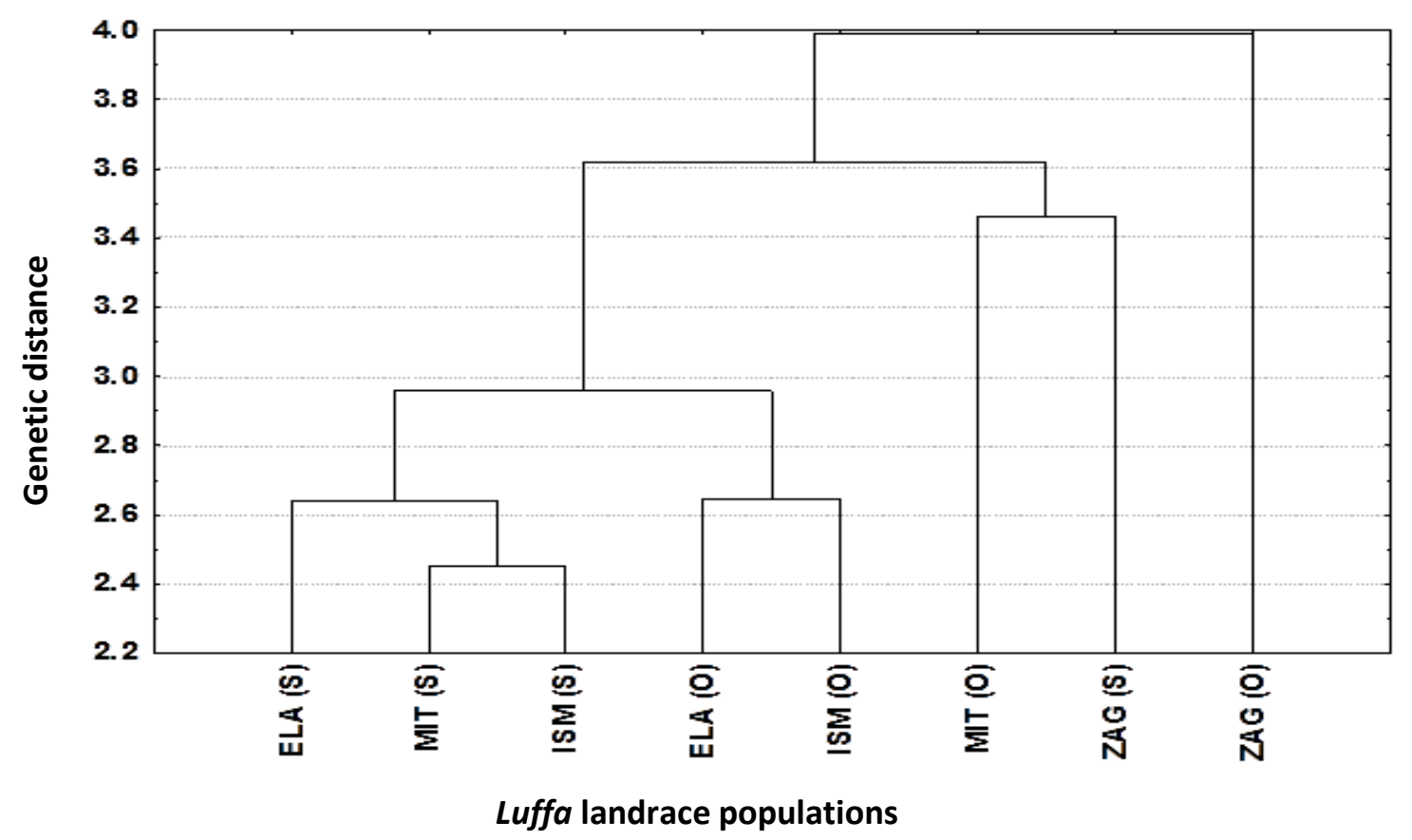

Fig. 2. Linkage dendrogram of studied $L$ uffa landraces based on combined analysis of amplified RAPD-PCR products after using all primers

El-Arish and Ismailia .This is meaning that the selfed and open pollinated landraces of El-Arish and of Ismailia were distributed into two subclusters. However, the selfed landrace of Zagazig and the open pollinated landrace of Meet-Gamr were grouped together into cluster II. While, the open pollinated landrace of Zagazig formed a single cluster by its self. In this regard, Hoque and Rabbani (2009) examined genetic divergence among twenty eight landraces of ridge gourd using RAPD-PCR products and found that these landraces distributed into five clusters. However, Mohammed et al. (2012) reported that a collection of smooth and ridge gourds was distributed, based on DNA-RAPD markers, into three major clusters. Smooth gourds were occupied a separate cluster together. Moreover, Prakash et al. (2014) found that some accessions belonging to five Luffa species were distributed into three clusters, using some ISSR markers.

The relative low genetic distances among the studied Luffa landraces might suggest that RAPD molecular divergences were generally consistent. Such genetic distances indicated that genetic relationships identified using RAPDPCR technique appeared to be suitable in revealing genetic variability, relatedness and consequently polymorphism among these open and self-pollinated Luffa landraces. The use of more RAPD primers might give large numbers of RAPD markers for such a molecular polymorphism analysis.

\section{REFERENCES}

Bharathi, L., S. Paridi, T. Behera and K.R. Raman (2011). Molecular diversity and genetic relationship of gourd of Indian Occurrence. Gen. Res. Crop Evol., 7:1-12.

Dellaporta, S.I., J. Wood and J.B. Hicks (1983). A plant DNA mini preparation. Ver III Plant Mol. Biol., 1: 19-21.

Hoque, S. and M.G. Rabbani (2009). Assessment of genetic relationship among landraces of Bangladeshi ridge gourd Luffa acutangula (Roxb) using RAPD markers, J. Sci. Res., 1 (3) : 615-623.

Lynch, M. (1991). Analysis of population genetic structure by DNA fingerprinting. In T. Burke, G. Dolf, A.J. Jeffrey and R. Wolff (eds.), DNA Fingerprinting: Approaches and applications. Spp. 113-126. Brikhauser Verlag, Basel. 
Modi, A. and V. Kumar (2014). Luffa echinata Roxb- on its phytochemical and pharmacological prospective. Asian Pac. J. Trop. Dis.

Mohammed, I.A., A.N. Gumaa, N.N. Kamal and Y.S. Alenor (2012). Genetic diversity among some cucurbits species determined by markers.Inter. J. Pl. Res., 2(4):131-137.

Partap, S., A. Kumar, N.K. Sharma and K.K. Jha (2012). Luffa cylindrical:An important medicinal plant. J. Nat. Prod. Pl. Resour., 2 (1): 127-134.

Prakash, K., J. Radhamani, A. Pandey and S. Yadav (2014). A preliminary investigation of cultivated and wild species of Luffa for oil and protein contents. Pl. Genet. Res., 12 (1): 103-111.
Rasmi, J. and J. Steelathakumary (2011). RAPD markers of genetic variability studies in ash gourd. J. Agric. Technol., 7: 1097-1106.

Sharma, J.K. (2006). Statistical and Biometrical Technique in Plant Breeding. New Age Int. Publish. New Delhi, India, 358.

Terh, L. (2007). The Luffa-for food,sponge and more Green Culture, Singapore feature Article Publish. Singapore.

Williams, J.G.K., A.R. Kubelik, K.J. Livak, J.A. Rafalski and S.V. Tingey (1990). DNA polymorphisms amplified by arbitrary primers are useful as genetic markers. Nucl.Acids Res., 18: 6531-6535.

Xia, J.H. and C. Xiang (2008). Analysis of genetic diversity in Luffa via morphological and RAPD markers, China Veget., 10 :21-25.

\section{RAPD-PCR دراسات على تعدد الصور الوراثية في اللوف المصري باستخدام$$
\text { سلمى عبدالبليع السيد سعود ـ سلامة ميخائيل عبد السيد }
$$

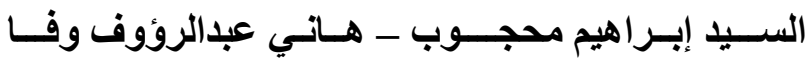

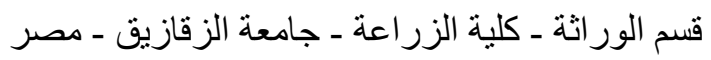

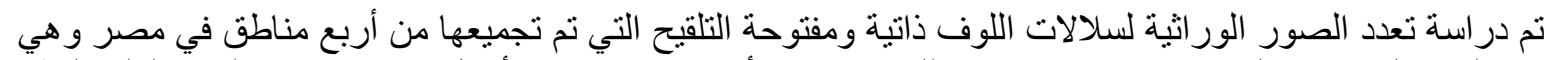

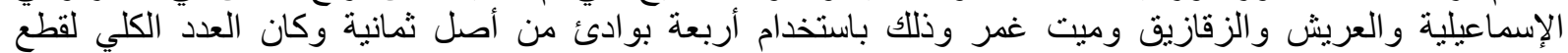

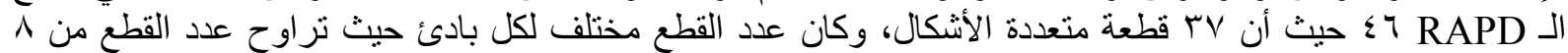

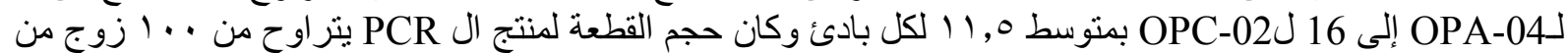

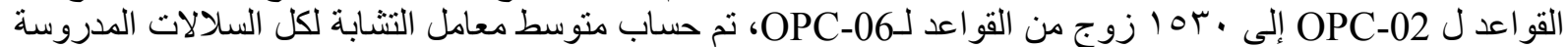

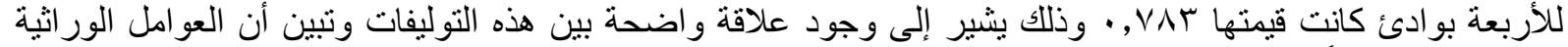

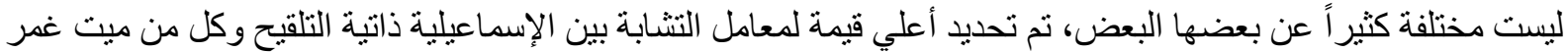

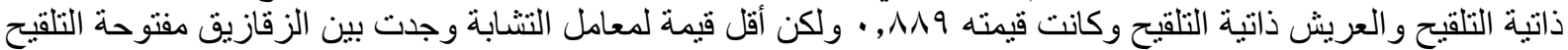

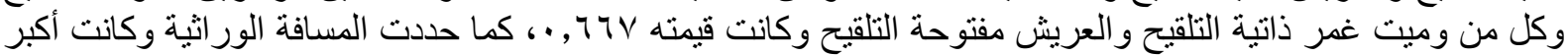

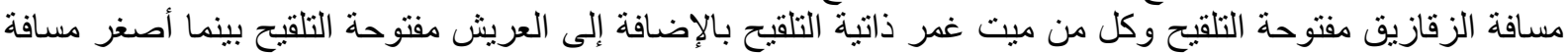

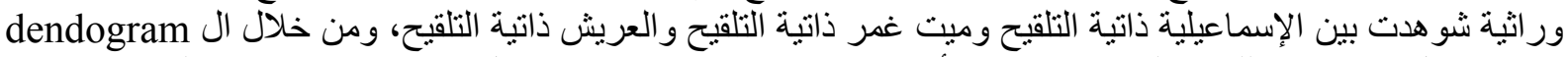

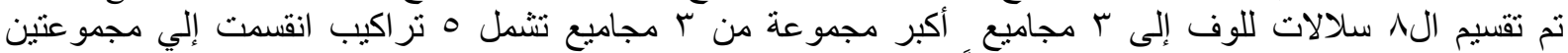
فرعيتين، يعتبرتكنيك م: مناسباً لدراسة الإختلافات الور اثثية والقرابة وتعدد الصور الور اثية بين سلالات اللوف التي تم در استها. 